\title{
WSRC-MS-2000-00212
}

\section{U.S. Field Testing Programs and Results}

\author{
G. G. Wicks \\ Westinghouse Savannah River Company \\ Aiken, SC 29808
}

This document was prepared in conjunction with work accomplished under Contract No. DE-AC09-96SR18500 with the U.S. Department of Energy.

\section{DISCLAIMER}

This report was prepared as an account of work sponsored by an agency of the United States Government. Neither the United States Government nor any agency thereof, nor any of their employees, makes any warranty, express or implied, or assumes any legal liability or responsibility for the accuracy, completeness, or usefulness of any information, apparatus, product or process disclosed, or represents that its use would not infringe privately owned rights. Reference herein to any specific commercial product, process or service by trade name, trademark, manufacturer, or otherwise does not necessarily constitute or imply its endorsement, recommendation, or favoring by the United States Government or any agency thereof. The views and opinions of authors expressed herein do not necessarily state or reflect those of the United States Government or any agency thereof.

This report has been reproduced directly from the best available copy.

Available for sale to the public, in paper, from: U.S. Department of Commerce, National Technical Information Service, 5285 Port Royal Road, Springfield, VA 22161, phone: (800) 553-6847, fax: (703) 605-6900, email: orders@ntis.fedworld.gov online ordering: http://www.ntis.gov/support/ordering.htm

Available electronically at http://www.osti.gov/bridge/

Available for a processing fee to U.S. Department of Energy and its contractors, in paper, from: U.S. Department of Energy, Office of Scientific and Technical Information, P.O. Box 62, Oak Ridge, TN 37831-0062, phone: (865 ) 576-8401, fax: (865) 576-5728, email: reports@adonis.osti.gov

\begin{abstract}
The United States has been active in four major international in-situ or field testing programs over the past two decades, involving the burial of simulated high-level waste forms and package components. These joint international efforts include (1) burial of over 100 simulated Savannah River Site (SRS) high-level waste glass samples in the granite site at Stripa in Sweden, (2) burial of SRS glasses in clay at Mol, Belgium, (3) in-situ testing of SRS waste forms and natural glass analogs in limestone at Ballidon in the United Kingdom and (4) field testing of almost 2000 SRS and international waste form samples and package components in the salt site at the Waste Isolation Pilot Plant (WIPP) in the United States. These programs are designed to supplement laboratory testing studies in order to obtain the most complete and realistic picture possible of waste glass behavior under realistic repository-relevant conditions. Waste glass performance thus far, has been seen to be very good, and even better in the field than would be predicted by many so-called standardized laboratory leaching tests.
\end{abstract}




\section{Background}

Located in the United States today are approximately 100 million gallons of high-level radioactive waste containing in excess of one billion curies of radioactivity. Most of this inventory is a result of defense programs and is handled and managed on three main sites; the Hanford reservation in Richland, Washington, the Savannah River Site in Aiken, South Carolina and the Idaho Chemical Processing Plant at Idaho Falls. While most of this inventory by volume is at Hanford, most of the radioactivity is contained at Savannah River (1).

A long-term objective of the high-level waste management program at the Savannah River Site (SRS), in Aiken, South Carolina, is to safely and effectively immobilize, approximately 34 million gallons of high-level radioactive waste (HLW), into high integrity, waste glass forms. This waste has been stored for many years in a liquid or semi-liquid form in large underground tanks on site. The waste is now being removed from these storage vessels and sent to a vitrification building, the Defense Waste Processing Facility (DWPF), where it is being processed into borosilicate waste glass logs. The waste glass products are currently being stored on site in an interim storage building, before they will be shipped to a geologic federal repository for permanent disposal. An important part of the immobilization strategy is to produce high quality waste glass products and ultimately, to understand and assess waste glass behavior, especially in the final resting place of the forms, the geologic repository. In order to assess, understand and to be able to predict the long-term behavior of these waste glass products, a multi-phase experimental effort has been in progress for several decades (2).

An important part of the SRS waste glass program involves assessing glass behavior under geologic, repository-relevant conditions, which includes (a) laboratory-scale waste glass leaching studies, (b) repository simulation tests (ex., rock-cup experiments), and (c) in-situ or field experiments. The most realistic tests that can be performed are also the most complex, and are representative of field or in-situ experiments. By combining all of these elements of the repository-related program, with those of the remaining integrated program, one can obtain the most complete picture possible of the performance of waste glass products. This paper will provide an overview of U.S. field testing efforts and discuss in more detail, results for in-situ testing of SRS waste glasses in the Materials Interface Interactions Tests or MIIT program $(3,4)$.

\section{International In-Situ Testing Programs}

\section{A. Stripa Tests (Sweden- granite)}

The first major international field tests, involving burial of simulated U.S. high-level waste glass forms and potential package components, was begun in 1982. These tests were conducted in the granite site of the Stripa mine located in Sweden (Figure 1a). This joint effort was conducted by the Swedish Nuclear Fuels Safety Division of the Nuclear Fuel Supply Co. (SKBF/KBS) in Sweden, and involved the participation of a variety of countries and facilities, including the University of Florida and the Savannah River Site, from the U.S. (5). Over 100 simulated SRS waste glasses were buried and over the next several years, samples were extracted from burial, analyzed, and results documented by the team. The samples were fabricated in the shape of "pineapple slices" and "mini-cans" with holes down the centers so they could be stacked on heater rods and heated to $90^{\circ} \mathrm{C}$ temperatures after emplacement. Various stacking sequences were used which involved waste form samples as well as potential package components, including canister and overpack metals as well as possible backfill materials. The interfaces and subsequent interactions were examined and characterized by a variety of analytical techniques. 


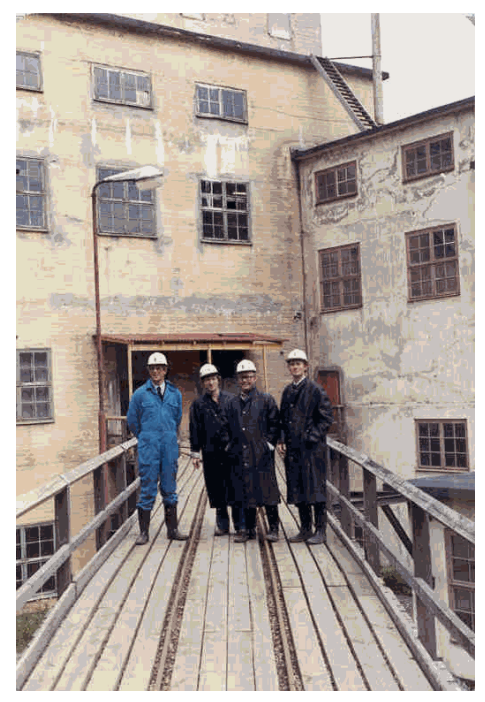

Figure 1a. Stripa Mine Entrance

Among the objectives of this joint study was to evaluate the behavior of the SRS waste glass forms as part of a multi-barrier waste isolation system and in a realistic geologic repository setting (Figure 1b). This effort also helped to establish a characterization methodology for comparing and assessing field data with laboratory test results and using these data to better define leaching mechanisms and long term performance of waste glass systems.

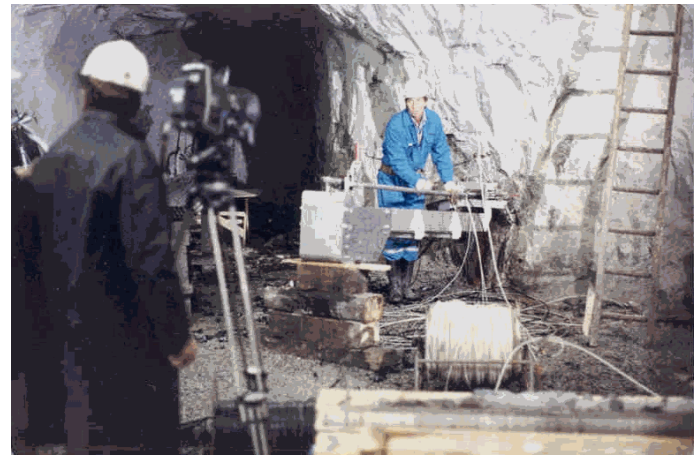

Figure 1b. Installation of In-Situ Tests Underground

It was found from this study that the SRS waste glass compositions performed very well in the field, in fact even better in the field than would be expected from many so-called 'standard laboratory leaching tests' (6-8).

\section{B. MOL Field Tests (Belgium- boom clay)}


The HADES (High Activity Disposal Experimental Site) Underground Research Facility is part of the $\mathrm{SCK} / \mathrm{CEN}$ Nuclear Research center at Mol and is located in boom clay in the northeast part of Belgium. This important and unique underground research facility (URL) is financially supported by the European Communities and its primary mission is to conduct a wide range of experiments related to disposal of high-level and long-lived radioactive wastes. Major tests conducted include geomechanics, hydrology, corrosion, waste form studies, and retention and migration of radionuclides This URL became operational in 1983 and was expanded in 1987 with an additional experimental gallery, which further increased in situ testing possibilities. In Figure $2 \mathrm{a}$, the underground facility is shown and in Figure $2 \mathrm{~b}$, a test assembly prior to emplacement (9).

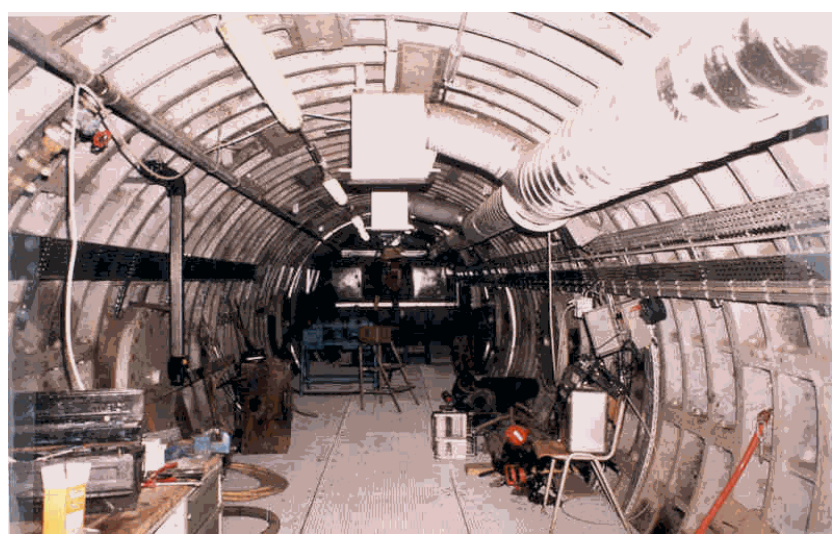

Figure 2a. HADES URL in Mol, Belgium

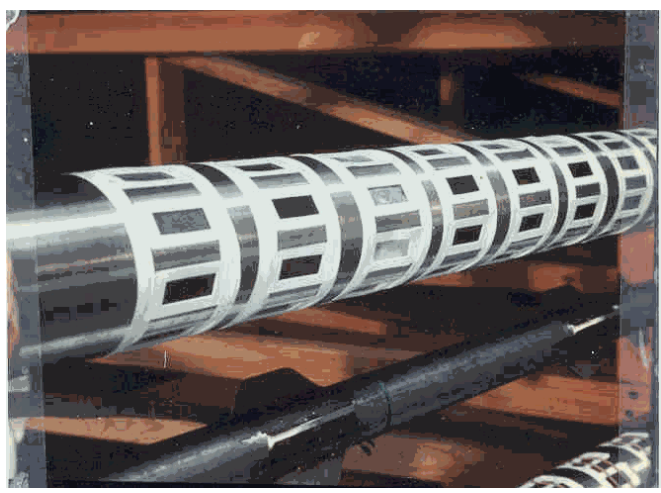

Figure 2b. Samples Loaded in Test Assemblies Prior to Emplacement

The HADES underground research laboratory is considered by many as the best research facility of its type in the international waste management community. Over the years, many excellent studies and important results have been obtained, relevant to waste management efforts around the world, which, have been well documented (10). In 1986, a series of SRS simulated HLW glass samples, similar in composition to those used in the Stripa study, became part of the Hades program. These samples were in the configuration of rectangles and were placed in the stainless steel assemblies shown in Figure 2b, before being buried in Boom clay approximately 224 meters below the surface. They were buried for 2 
years at temperatures of $90^{\circ} \mathrm{C}$ and also ambient conditions $\left(16^{\circ} \mathrm{C}\right)$. Analyses of these glasses showed leaching depths of the glasses larger than observed in the Stripa tests, with both selective and congruent dissolution occurring (11). These data and information were very useful not only with respect to geologic burial sites, but also for potential clay-like backfills that are also being considered as part of a mult-barrier isolation system for disposal of waste forms.

\section{Ballidon Field Tests (England- limestone)}

An interesting study was initiated in 1970 by the British Glass Industry Research Association and involved the burial of archaeological and modern glass specimens in carboniferous limestone at Ballidon in Derbyshire, in the United Kingdom. The original objective was to bury commercially relevant glass formulations and to dig them out and assess them after time periods of 1, 2, 4, 8, 16, 32, 64, 128, 256, and 512 years. The descriptions and compositions of the original glasses, along with shapes and measurements, are described elsewhere by Fletcher and Newton (12-14).

In 1986, following extraction of samples at five sites within the mound, a joint effort was started between the Savannah River Site and Dr. Roy Newton, of the University of Sheffield, involving emplacement of an additional 46 samples in the recently vacated positions (Figure 3 ). This included a series of SRS simulated HLW glasses, along with a standard glass and a glass analog. Samples were to be retrieved at time periods of 1, 2, 5, and 16 years. The 1, 2, and 5 year samples have been excavated, characterized and evaluated and are reported elsewhere $(15,16)$. The 16-year samples are scheduled to be retrieved in the year 2002.

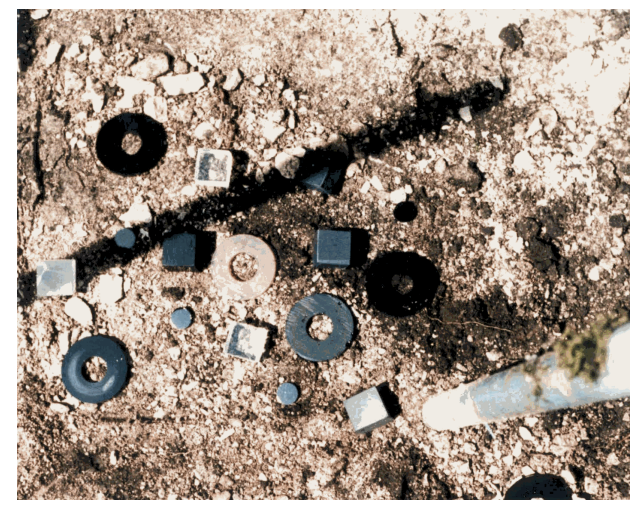

Figure 3. SRS Glass Samples being Buried at Ballidon, UK

These Ballidon tests represent the simplest of the field tests involving burial of U.S. glasses. All the tests were conducted at ambient temperature and simply involved digging holes into the limestone mound and burying the glasses in shallow formations, which were then marked by pole markers. Post burial analyses of these glasses showed that they exhibited very good durability in the limestone environment and produced two major leaching regions; an outermost precipitated layer several microns thick and below that, a glass interaction zone, less than one micron thick, which also consisted of sub-layers.

\section{WIPP MIIT Tests (U.S.- salt)}

The mission of the Waste Isolation Pilot Plant or WIPP was defined by the U.S. Congress as "providing 
a research and development facility to demonstrate the safe disposal of radioactive waste resulting from the defense activities and programs of the United States". Construction of the WIPP began in 1981 in the salt beds in Carlsbad, New Mexico. The WIPP excavation consists of more than four miles of tunnels at a depth of approximately 655 meters in the Salado Formation. This facility will be used to (a) permanently isolate transuranic (TRU) waste generated from U.S. defense programs, and (b) to serve as an "underground laboratory" to evaluate and demonstrate safe and effective disposal of TRU wastes (simulated and actual), as well as defense high-level waste (simulated DHLW only) (17-19).

The Materials Interface Interactions Test (MIIT) program, started in 1986, represents the first in-situ or field tests to be conducted in the United States, involving burial of simulated (non-radioactive) highlevel waste glasses and potential package components $(20,21)$. Included in the study were over 900 waste form samples comprising 15 different systems supplied by 7 countries. Also included were almost 300 potential container or overpack metal samples of 11 different metals along with more than 500 geologic and backfill specimens. There were almost 2000 relevant interactions that characterized this 5year field testing effort, which was conducted in the bedded salt site at the Waste Isolation Pilot Plant (WIPP), near Carlsbad, New Mexico (22). The MIIT program involved the participation of a variety of national and international organizations, laboratories and universities in France, Germany, Belgium, Canada, Japan, the United Kingdom, Sweden, as well as the United States. This program represents one of the largest, most cooperative ventures of its type in the international waste management community. The 50 MIIT assemblies and their installation at WIPP are shown in Figures $4 \mathrm{a}$ and $4 \mathrm{~b}$.

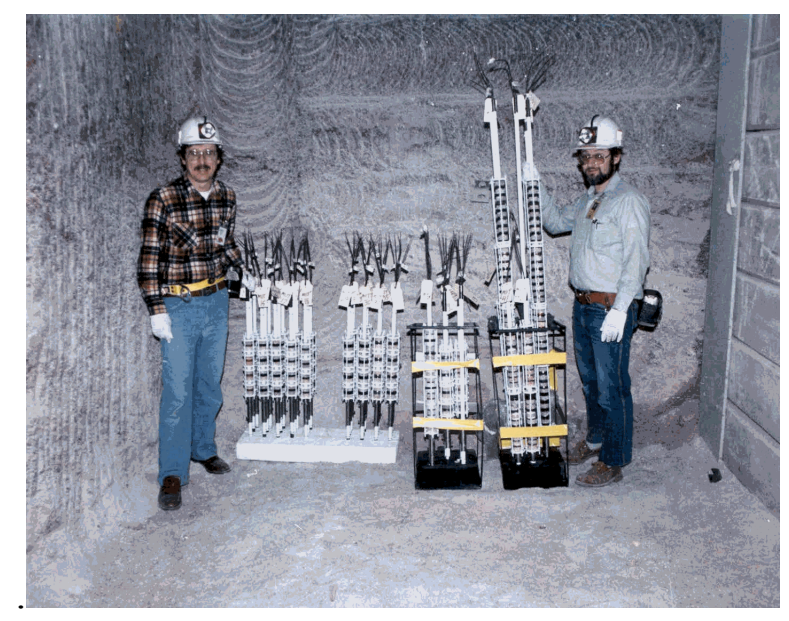

Figure 4a. 50 MIIT Assemblies Prior to Installation 


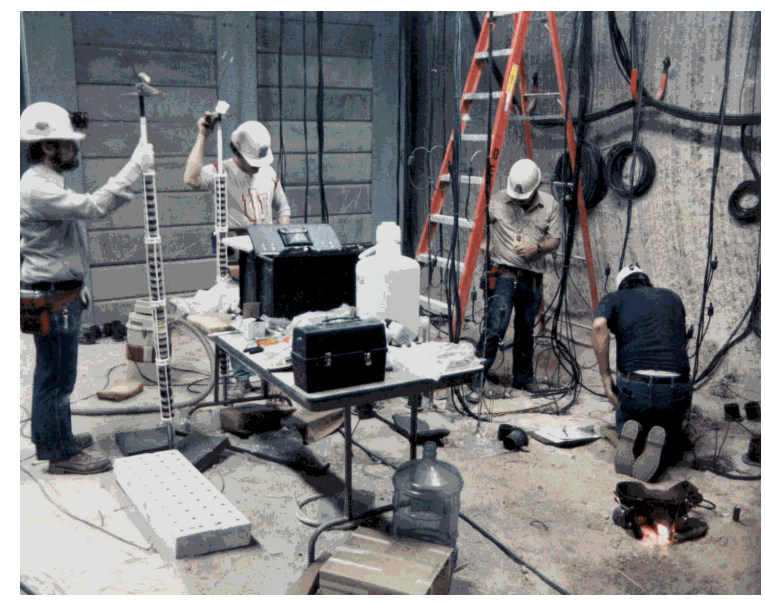

Figure 4b. Installation of MIIT Test Assemblies in WIPP

MlIT was operated and managed jointly by the Savannah River Site (Aiken, South Carolina) and Sandia National Laboratories (Albuquerque, New Mexico), and sponsored by the U.S. Department of Energy. There were many participants involved, some who supplied samples, others who conducted post-test analyses and some who participated in a Peer Review process of the effort. U.S. participants included the Hanford Waste Vitrification Project, Battelle Pacific Northwest Laboratory, the University of Florida, Catholic University of America, University of New Mexico, the Pennsylvania State University, Clemson University, and the Materials Characterization Center. International representatives include Hahn-Meitner Institute and Kernforschungszentrum Karlsruhe (Germany), Centre D'Etudes Nucleaires (France), the Atomic Energy of Canada, Ltd. (Canada), British Nuclear Fuels, Ltd. (United Kingdom), Studiecentrum Voor Kernenergie/Centre D'Etude de L'Energie Nucleaire (Belgium), Japan Atomic Energy Research Institute (Japan), and the Chalmers Institute of Technology (Sweden) (23-25).

There were many unique features associated with the design of the MIIT experiments. Among the most important features was that meaningful solution data could be obtained for the first time in a field experiment involving burial of the U.S. waste glasses. This represented an important contribution to assessing and understanding waste glass leaching behavior. Glass, metal, and geologic samples, along with brine leachate solutions, were obtained from WIPP at pre-determined time intervals over the 5-year testing program. A summary of some of the more interesting and relevant findings, involving SRS waste glass evaluated in the MIIT program, is given below (26):

\section{MIIT RESULTS}

A. Compositional Correlations. The compositions of the different waste forms provided by each of the international participants in MIIT have been correlated by Ramsey and Wicks using compositional ternaries (27). These interesting correlations were made based on structural considerations, bonding energies, and surface layer characteristics. These efforts suggest that for the variety of waste glass systems studied world-wide, the behavior of many of these systems, such as the borosilicate waste forms, should be very similar, including leaching mechanisms. In Figure 5, a compositional ternary relating MIIT systems based on structural role of components as network formers, intermediates and modifiers within the random network of glass, is shown. 


\section{COMPOSITION CORRELATIONS}

\section{US \& International Waste Glasses}

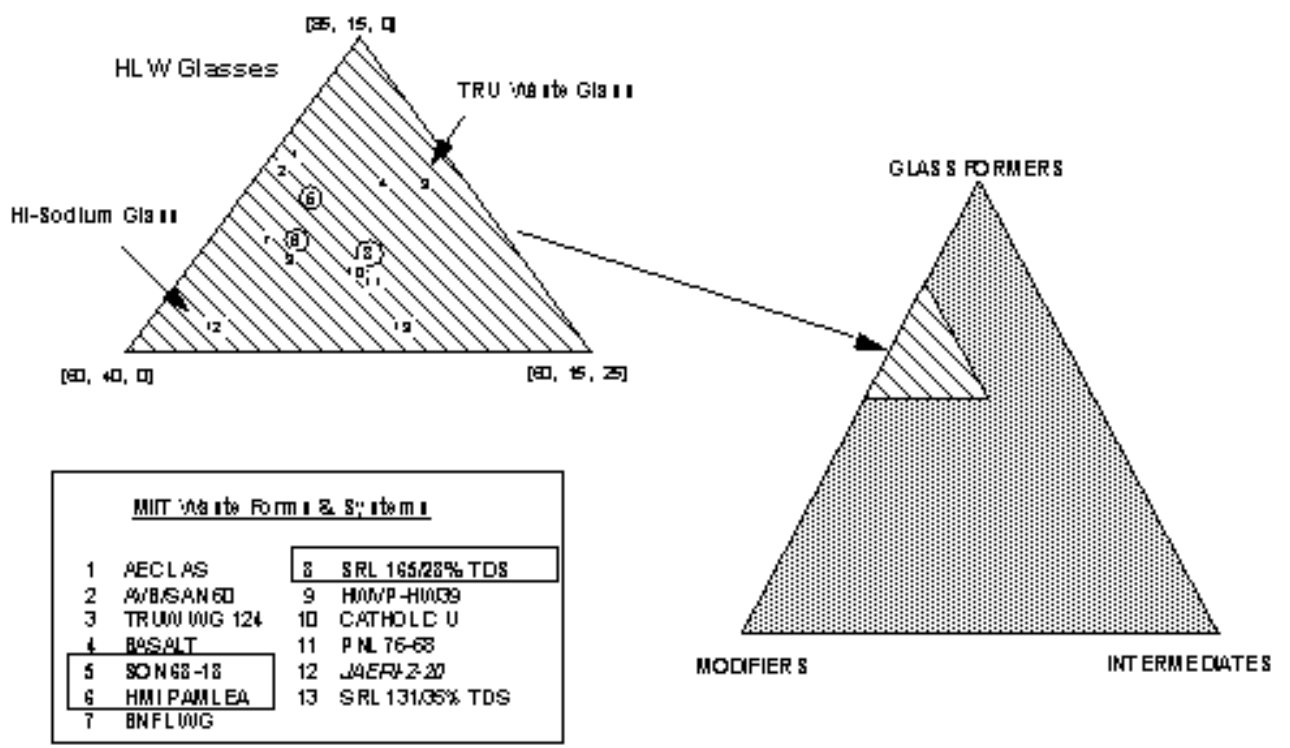

Figure 5. Compositional Correlations of MIIT Waste Glass Compositions

B. Post-Test Analyses of SRS Waste Glass (SRS 165/TDS). An integrated study approach was used to characterize and assess waste form behavior and the interaction layers and zones produced during burial. The performance of SRS waste glass, based on .both (a) surface studies and (b) solution analyses, was seen to be very good, after burial in the salt environment at WIPP for time periods of 1, 2 and 5 years (4, 28-31).

Integrated Study Approach. The integrated study approach combines solution analyses with detailed bulk and surface studies of reacted waste forms. A variety of analytical techniques were used to characterize the composition, chemistry and structure of glass and waste components on, in and through leached surface layers. Depth profiling was also used. The present study emphasized Optical Microscopy (OM), Scanning Electron Microscopy (SEM), Energy Dispersion X-rays (EDX), Electron Microprobe Analysis (EMP), Secondary Ion-Mass Spectrometry (SIMS), Auger Electron Spectroscopy (AES), Transmission Electron Microscopy (TEM), Fourier Transform Infrared Reflection Spectroscopy (FTIRRS) and Wide Angle X-ray Diffraction (WAXD). In addition to the various bulk and surface studies performed, solution analyses of brine leachates was conducted using Inductively Coupled Plasma Mass Spectroscopy (ICP-MS). The integrated study approach and the analytical techniques used are summarized in Figure 6. 


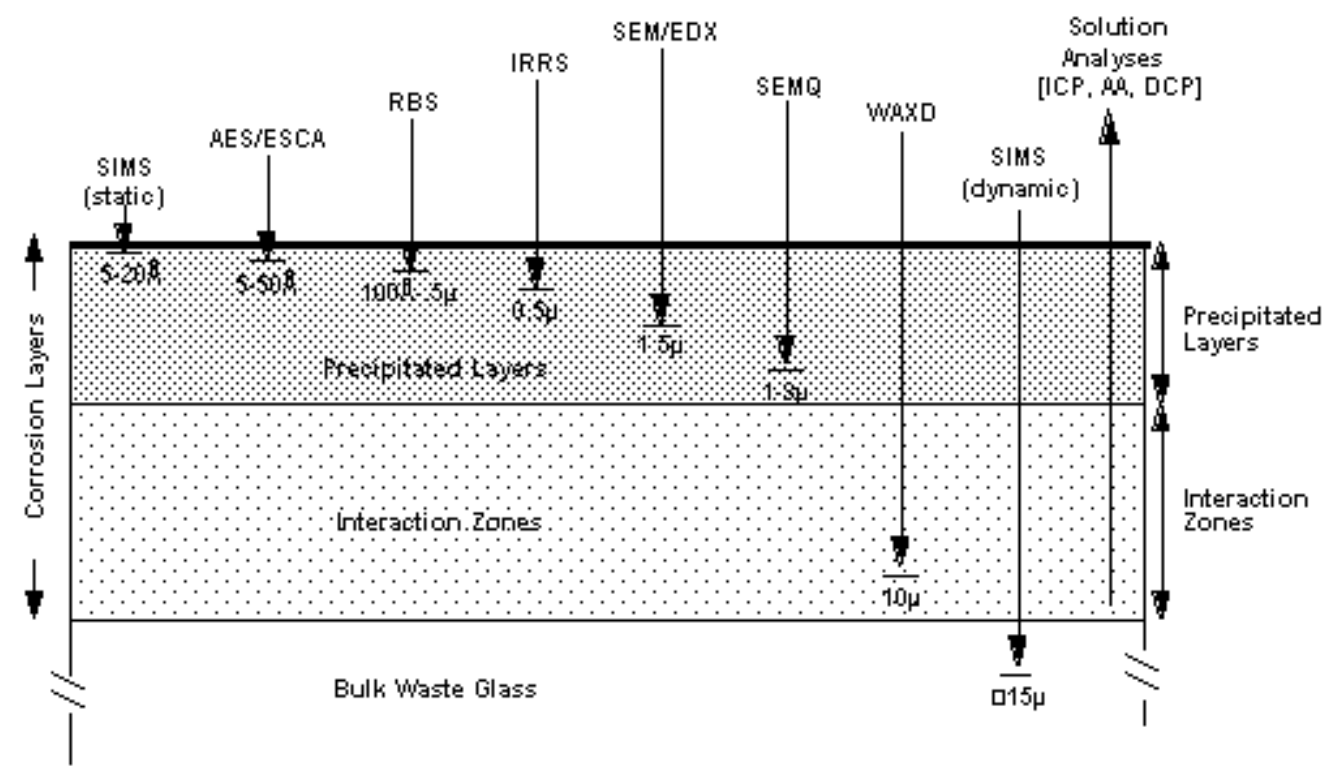

Figure 6. Analytical Tools Used to Study MIIT Glasses

Precipitated and Glass Reaction Zones. Precipitated and glass reaction zones were analyzed and measured as a function of time and other relevant conditions by Tacca and Wicks (32). In Figure 7, a cross-section of SRS waste glass and accompanying composition of the major layers formed during burial, is shown, using SEM/EDX. As noted in this figure, are two distinct regions observed using these techniques; an outermost precipitated layer and a inner glass reaction zone. The outermost layer consists mainly of precipitated salt phases and includes crystalline as well as amorphous regions as determined by SEM, EDX and wide angle X-ray diffraction [WAXD]. These phases were attributed to the brine and salt precipitates that form on the glass surface during the MIIT leaching tests. There are two important points to note concerning the glass reaction region underneath the precipitated layers; 1) the amount of interaction of the glass with surrounding brine environment, as measured by the intrusion of $\mathrm{Mg}$ and $\mathrm{Cl}$ from the brine into the glass, is very low and 2) the rate of interaction decreases with increasing time. These observations indicated that chemical durability of the glass is very good and actually becomes better with increasing time. 


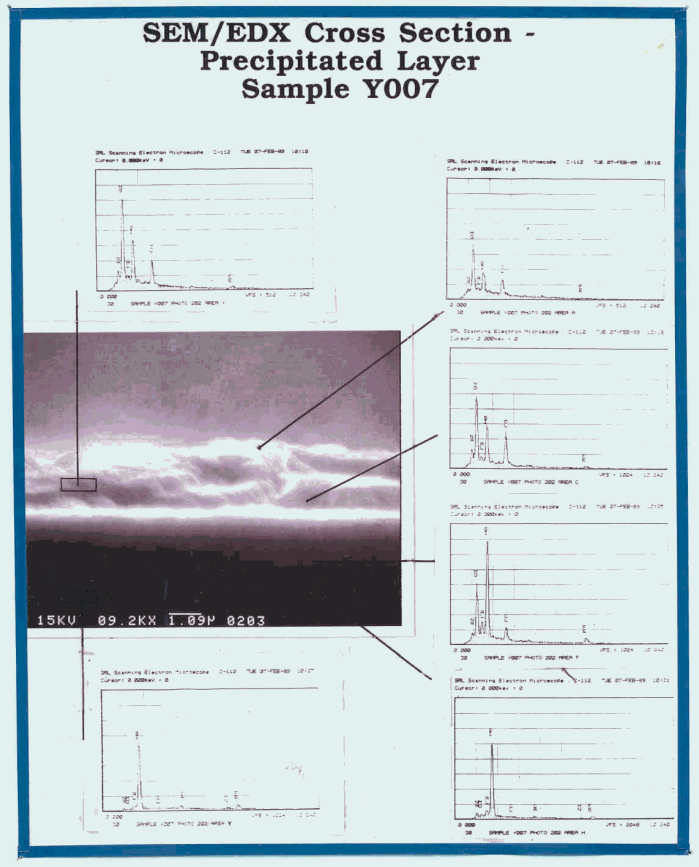

Figure 7. SEM/EDX Cross Section of Precipitated and Leached Layers

The reacted glass surfaces were investigated in more detail by other analytical techniques, including Fourier Transform Reflection Spectroscopy [FTIRRS], by Clark, Zoitos and co-workers at the University of Florida (33), and by Secondary Ion Mass Spectroscopy, by Lodding et. al. of Chalmers University in Sweden (34,35). FTIRRS showed that the disruption to the glass structure was qualitatively small, while SIMS provided one of the most detailed tools for mapping individual elements throughout leached layers of the burial glasses. SIMS showed that the precipitated layer actually consists of two individual layers and the reaction zone of the glass consists of at least three individual leached layers [Figure 8] (35). The SIMS technique is discussed in more detail by Lodding elsewhere (36). 


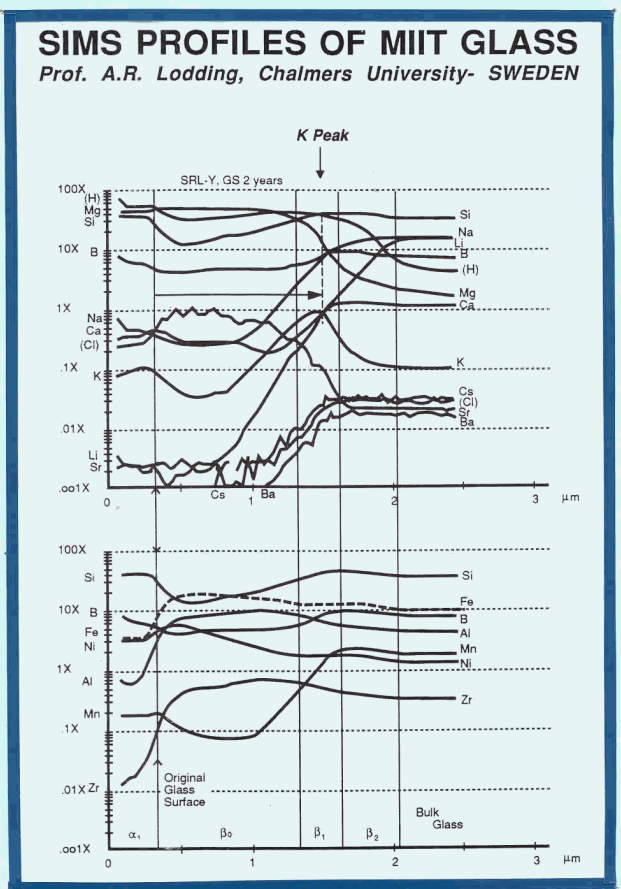

Figure 8. SIMS Profiles of SRS Waste Glass (2 years Burial in WIPP/ G-G Interfaces)

By combining studies of SEM, EDX, FTIRRS, WAXD, TEM, EMP, and most importantly, the SIMS studies of Lodding, a composite picture of leaching of SRS waste glass in WIPP was developed and is summarized in Figure 9 (37).

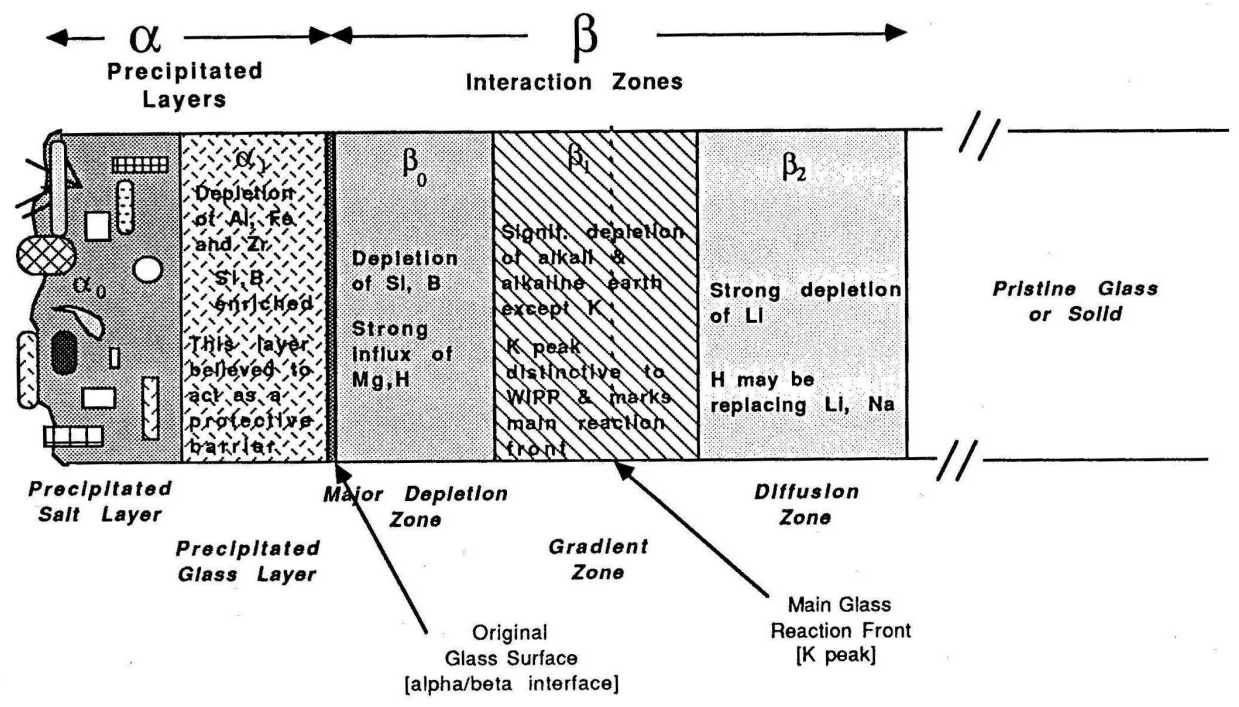

Figure 9. Schematic Representation of Precipitated and Leached Layers in MIIT Waste Glasses 
Each of the various precipitated and reacted glass layers are discussed below:

$\alpha_{\mathrm{o}}$ - Outermost Precipitated Salt Layer; The outermost precipitated layer was studied by Vernez of the CEA in France (38), Harker of Rockwell International (39), Ewing of the University of New Mexico (40) and SRS. Both amorphous as well as highly crystalline phases were observed, including $\mathrm{MgCl}_{2}$, $\mathrm{KCI}, \mathrm{CaSO}_{4}, \mathrm{NaCl}$, and a variety of mixed silicates, along with additional minor phases. The layer was generally very heterogeneous and varied in thickness. The chemistry of the layer was dominated by large quantities of $\mathrm{Mg}$ and $\mathrm{CI}$ derived from the suffounding brine, along with other components such as $\mathrm{Ca}, \mathrm{Na}, \mathrm{S}$, and $\mathrm{Si}$. The salt layer, which was formed primarily as a result of the geologic environment and not from leaching the glass, is expected to effect subsequent glass leaching.

$\alpha_{1}$ - Precipitated Glass Layer; Under the outermost precipitated salt layer,immediately adjacent to the glass surface is a thin, precipitated glass layer. This layer formed when elements from the glass leached and precipitated in this region. The layer is more uniform than the salt precipitated layer and characterized by large amounts of elements from the brine, including $\mathrm{Mg}$ and $\mathrm{Cl}$, along with $\mathrm{Si}$. This layer is also relatively depleted in elements such as $\mathrm{Al}, \mathrm{Zr}$, and $\mathrm{Fe}$, which are generally the least leachable species within the glass. This observation, along with ratios of other components present, morphology and subsequent brine analysis of leachate, show that this is a precipitated region and not a selectively leached part of the original glass.

$\beta_{\mathrm{o}}$-Major Depletion Zone; Directly under the precipitated layers is where glass begins and represents a major deletion zone in the outermost glass surface. Here major components of the glass are depleted in this area. The region is further characterized by the intrusion of major brine components such as $\mathrm{Mg}$. The original glass surface, the $(\alpha / \beta$ interface, is located in this region.

$\beta_{1}$-Gradient Zone; Below the major depletion zone is the gradient zone, which is characterized by depletion of alkali and alkali earth components of the glass and enrichment in the main brine component, $\mathrm{Mg}$. One of the most interesting features of this zone is the presence of a potassium peak. The distance from the $\alpha / \beta$ interface or glass surface to the potassium peak in the $\beta_{1}$ zone, represents the main reaction front of the glass after interacting with the surrounding environment.

$\beta_{2}$ - Diffusion Zone; This innermost glass leached layer is believed to be similar to the gel layer which initially forms on simple glasses during leaching. The zone is characterized by depletion in Li from the glass and enrichment of $\mathrm{H}$ from the solution. The thickness is consistent with diffusion calculations of these components in the bulk glass.

B. Brine Analyses. The MIIT program is the only in-situ testing effort of this type which allows solution analyses to be obtained and subsequently, correlated with surface studies. Brine analyses were performed on leachates from selected boreholes containing SRL 165/TDS waste glass undoped and glass doped with $\mathrm{Eu}$ and $\mathrm{Yb}$ as chemical tracers. After measuring concentrations found in solution, ]each rates were calculated based on sample characteristics and testing conditions. In addition to assessing glass performance in the field, the solution analyses were used to define the original position of the glass surface in more detail. Analyses were performed by Macedo and co-workers at the Catholic University of America and are summarized in Table $1(41,42)$. 


\begin{tabular}{|c|c|c|}
\hline Waste Glass Systems & $\begin{array}{c}\text { Leachrates }\left(\mathrm{X} 10^{4}\right) \\
{\left[\mathrm{g} / \mathrm{m}^{2} \mathrm{~d}\right]}\end{array}$ & $\begin{array}{c}\text { Leach Depths } \\
{[\mu \mathrm{m} / \mathrm{yr}]}\end{array}$ \\
\hline \multicolumn{3}{|l|}{\begin{tabular}{|l} 
A. SRS 165/TDS \\
\end{tabular}} \\
\hline $\mathrm{Zr}$ & 1.6 & 0.02 \\
\hline $\mathrm{Li}_{\mathrm{i}}$ & & 0.36 \\
\hline La & 3.5 & 0.042 \\
\hline $\mathrm{Eu}$ & 3.0 & 0.036 \\
\hline \multicolumn{3}{|l|}{ B. FR JSSA } \\
\hline $\mathrm{Y}$ & 7.4 & 0.090 \\
\hline $\mathrm{Ce}$ & 1.2 & 0.014 \\
\hline $\operatorname{Pr}$ & 3.1 & 0.027 \\
\hline Nd & 1.2 & 0.015 \\
\hline
\end{tabular}

Table 1. Leachrates and Leaching Depths of MIIT Glasses Based on Brine Analyses

There are several important observations that can be made from these data. First, the leaching behavior of SRL glass is very similar to other important international waste glass compositions used in this study. This includes the Japan- Switzerland- Sweden [JSS] composition. This observation was predicted by the compositional ternaries discussed earlier. Next, the actual leach rates are very low, generally less than 1

$\mathrm{g} / \mathrm{m}^{2}$-day. This is noted based on both brine analyses and by calculations of SIMS profiles, even for very mobile and non-radioactive species such as Li. Finally, if one takes into account the geometry of the stored waste, leaching depths can also be calculated and related to the Nuclear Regulatory Commission release rate criteria [10 CFR Part 60]. For the MIIT tests, these data showed a release rate of species of interest of less than one part in 100,000 for all elements investigated thus far $(37,41,42)$.

\section{Summary}

In-situ or field tests provide an important contribution to the overall goals of assessing, understanding and predicting long term behavior of waste forms in geologic burial sites. Field experiments are often complex and difficult to perform, but can also be the most realistic tests that can be conducted. They are especially useful for validating laboratory test findings and proposed modeling behavior, and contribute to providing additional assurance in the safe and effective disposal of radioactive wastes. Based on all data currently available, the performance of nuclear waste glass systems can be excellent, when tested under realistic conditions, as determined by many studies performed by many different investigators world-wide.

\section{References}

1. G.G. Wicks, "Nuclear Waste Glasses", Treatise on Materials Science and Technology, Glass IV, M. Tomozawa and R.H. Doremus, eds., 26, pp. 57-118, Academic Press Inc. (1985).

2. G.G. Wicks and D.F. Bickford, "Doing Something About High-Level Radioactive Waste", Technology Review, p.50 (1989).

3. G.G. Wicks, "Nuclear Waste Vitrification- The Geology Connection", J. NonCrystalline Solids, 84, p. 241, (1986).

4. G.G. Wicks, "Nuclear Waste Glasses; Corrosion Behavior and Field Tests", Corrosion of Glass, 
Ceramics, and Ceramic Superconductors, D.E. Clark and B.K. Zoitos, eds., pp. 218-268, Noyes Publication, Park Ridge, N.J. (1992).

5. L.O. Werme, "The Swedish Programme for In-Situ Testing of HLW Forms", in Testing of HighLevel Waste Forms Under Repository Conditions, Report EUR 12017 EN, T. McMenamin ed., p. 3, Commission of the European Communities, Belgium (1989).

6. D.E. Clark, B.F. Zhu, R.S. Robinson and G.G, Wicks, "Preliminary Report on a Glass Burial Experiment in Granite", Nuclear Waste Management, Advances in Ceramics, G.G. Wicks and W.A. Ross, eds., Am. Cer. Soc., Columbus OH, $\underline{8}$, p. 324 (1984).

7. B.F. Zhu, D.E. Clark, L.L. Hench, G.G. Wicks and L. Werme, "One-Year Leaching of Three SRL Glasses in Granite", Scientific Basis for Nuclear Waste Management VIII, C.M. Jantzen, J.A. Stone and R.C. Ewing, eds., 44, MRS, p. 187 (1985).

8. A. Lodding, E.U. Engstrom, D.E. Clark, L.O. Werme, and G.G. Wicks, "SIMS Analysis of Leached Layers Formed on SRL Glasses During Burial", Nuclear Waste Management 11, Advances in Ceramics, 20, D.E. Clark, W.B. White and A.J. Machiels, eds., Am. Cer. Soc., Columbus OH, p. 567 (1987).

9. A.A. Bonne, "The In-Situ Testing Programme in the HADES Facility", in Testing of High-Level Waste Forms Under Repository Conditions, Report EUR 12017 EN, T. McMenamin ed., p. 25, Commission of the European Communities, Belgium (1989).

10. "Publications and Open File Reports on Characterization of Conditioned Radioactive wastesDisposal of Radioactive Wastes into the Boom Clay (Mol site)", SCK/CEN, Mol, Belgium (1992).

11. R.L Schulz, D.E. Clark, G.G. Wicks, A.R. Lodding and P. Van Iseghem, "Characterization of Savannah River Glasses Buried in Boom Clay- The Hades Tests at Mol, Belgium", Ceramic Transactions, Environmental Issues and Waste Management Technologies 1111, D.K. Peeler and J.C. Marra, eds., 87, p.441 (1998).

12. W.W. Fletcher, "The Chemical Durability of Glass. A Burial Experiment at Ballidon in Derbyshire", J. Glass studies, 14, p. 149 (1972).

13. R.G. Newton, "Ballidon Glass Burial Experiment", Glass Technology, 26 No. 6, (1985).

14. R.G. Newton, "Future of the Ballidon Glass Burial Experiment", Glass Technology, 33, No. 5, (1992).

15. C.G. Namboodri, S.L.Namboodri, G.G. Wicks, A.R. Lodding, L.L. Hench, D.E. Clark, and R.G. Newton, "Surface Analyses of SRS Waste Glass Buried for up to Two Years in Limestone in the U.K.", Ceramic Transactions, Nuclear Waste Management IV, G.G. Wicks, D.F. Bickformd andL.R. Bunnell, eds., Am. Cer. Soc., Columbus OH, 23, p. 653 (1991).

16. R.L Schulz, D.E. Clark, G.G. Wicks, K. Welcher, A.R. Lodding, and R.G. Newton, "Surface Analyses of SRS Glasses Buried in Limestone for up to 5 Years", Ceramic Transactions, Environmental Issues and Waste Management Technologies in the Ceramic and Nuclear Industry, V. Jain and R. Palmer, eds., 61, p. 569 (1995).

17. Sandia Technology, Sandia National Laboratories, SAND 84-2326, $\underline{9}$, No. 1, Albuquerque, NM (1985).

18. R.V. Matalucci, C.L. Christensen, T.O. Hunter, M.A. Molecke, and D.E. Munson, "Waste Isolation Pilot Plant [WIPP] Research and Development Program: In Situ Testing Plan", SAND 81-2628, Sandia National Laboratories, Albuquerque, NM (1983).

19. "Waste Isolation Pilot Plant [WIPPI Program Plan for FY 84", Sandia National Laboratories Department 6330, Sandia National Laboratories, Albuquerque, NM (1983).

20. M.A. Molecke and G.G. Wicks, "Test Plan- WIPP Materials Interface Interactions Test Sandia National Laboratories, Albuquerque, NM (1985).

21. G.G. Wicks, "WIPP/SRL In Situ and Laboratory Testing Programs- Part 1: MIIT Overview, Nonradioactive Waste Glass Studies", DP-1706, Savannah River Laboratory, Aiken, SC (1985).

22. G.G. Wicks, M.E. Weinle and M.A. Molecke, "WIPP/SRL In Situ Tests- Part II: Pictorial History of MIIT and Final MIIT Matrices, Assemblies, and Sample Listings", DP-1733, Savannah River Laboratory, Aiken, SC (1987). 
23. W.G. Ramsey and G.G. Wicks, "WIPP/SRL In Situ Tests- Part III: Compositional Correlations of MET Waste Glasses", DP- 1769, Savannah River Laboratory, Aiken, SC (1988).

24. G.G. Wicks and M.A. Molecke, "WIPP/SRL In Situ Testing Program", Nuclear Waste Management II, Advances in Ceramics, D.E. Clark, W.B. White and A.J. Machiels, eds., Am. Cer. Soc., Columbus OH, 20, p. 657 (1986).

25. G.G. Wicks and M.A. Molecke, "WIPP/SRL In Situ Testing Program- MIIT Update 1988", Waste Management '88, II, p. 383 (1988).

26. Testing of High-Level Waste Forms Under Repository Conditions, Report EUR 12017 EN, T. McMenamin ed., Commission of the European Communities, Belgium (1989).

27. W.G. Ramsey and G.G. Wicks, "WIPP/SRL In Situ Tests: Compositional Correlations of MIIT Waste Glasses", Ceramic Transactions, Nuclear Waste Management III, G.B. Mellinger, ed., 9 , p. 317 (1990).

28. M.A. Molecke and G.G.Wicks, "Materials Interface Interactions Test (MIIT); Details and Observations on In Situ Sample Retrievals and Test Termination", to be presented at the Workshop on In Situ Testing of Radioactive Waste Forms and Engineered Barriers, Corsendonk, Belgium, October 13-16, 1992, and to be published in proceedings (1992).

29. G.G. Wicks, A.R. Lodding, P.B. Macedo, D.E. Clark, and M.A. Molecke, "MIIT; International In Situ Testing of Simulated HLW Forms- Preliminary Analyses of SRL 165/TDS Waste Glass and Metal Systems", High Level Radioactive Waste Management, 1, p. 443 (1990).

30. G.G. Wicks, A.R. Lodding, P.B. Macedo, and D.E. Clark, "MIIT; International In-Situ Testing of Simulated HLW Forms in Salt- Performance of SRS Simulated Waste Glass up to 5 Yrs. of Burial at WIEPP", Scientific Basis for Nuclear waste Managemen XV, Materials Research Society, Strasbourg, France, 257, p. 119 (1992).

31. G.G. Wicks, A.R. Lodding, P.B. Macedo, and D.E. Clark, "MIIT; Summary of the Performance of SRS Waste Glass Buried in Salt at W1[PP- 1992 Update", presented at the Workshop on In Situ Testing of Radioactive Waste Forms and Engineered Barriers, Corsendonk, Belgium, October 1316, 1992, and to be published in proceedings (1992).

32. J.A. Tacca and G.G. Wicks, "WIPP/SRL In Situ Tests: MIlT Program- Surface Studies of SRP Waste Glass", Ceramic Transactions, Nuclear Waste Management III, G.B. Mellinger, ed., 9 , p. 271 (1990).

33. D.E. Clark, B.K. Zoitos, G.G. Wicks and K.A. Molen, in Testing of High-Level Waste Forms Under Repository Conditions, Report EUR 12017 EN, T. McMenamin ed., p. 140, Commission of the European Communities, Belgium (1989).

34. A.R. Lodding, E.U. Engstrom, and H. Odelium, in Testing of High-Level Waste Forms Under Repository Conditions, Report EUR 12017 EN, T. McMenamin ed., p. 127, Commission of the European Communities, Belgium (1989).

35. A.R. Lodding, E.U. Engstrom, D.E. Clark, and G.G. Wicks, "Quantitative Concentration Profiling and Element Balance in SRL Glass After Two Years in WIPP", Ceramic Transactions, Nuclear Waste Management III, G.B. Mellinger, ed., $\underline{9}$, p. 317 (1990).

36. A.R. Lodding, "Characterization of Corroded Ceramics by SIMS", Corrosion of Glass, Ceramics, and Ceramic Superconductors, D.E. Clark and B.K. Zoitos, eds., pp. 103-121, Noyes Publication, Park Ridge, N.J. (1992).

37. G.G. Wicks, A.R. Lodding, P.B. Macedo, D.E. Clark and M.A. Molecke, "MIIT; International InSitu Testing of Simulated HLW Forms- Preliminary Analyses of SRL 165/TDS Waste Glass and Metal Systems", High Level Radioactive Waste Management, 1, p. 443, ANS (1990).

38. E. Vernaz and N. Godon, in Testing of High-Level Waste Forms Under Repository Conditions, Report EUR 12017 EN, T. McMenamin ed., p. 81, Commission of the European Communities, Belgium (1989).

39. A.B. Harker, J.F. Flintoff and D.G. Howitt, in Testing of High-Level Waste Forms Under Repository Conditions, Report EUR 12017 EN, T. McMenamin ed., p. 152, Commission of the European Communities, Belgium (1989). 
40. M.S. Jercinovic, S. Kaser and R.C. Ewing, in Testing of High-Level Waste Forms Under Repository Conditions, Report EUR 12017 EN, T. McMenamin ed., p. 183, Commission of the European Communities, Belgium (1989).

41. R.E. Sasson, M. Gong, M. Brandys, M. Adel-Hadadi, A. Barkatt and P.B. Macedo, "Analysis of Brine Leachates from MIIT- 1. Leaching of Nuclear Waste Glass Doped with Chemical Tracers", Ceramic Transactions, Nuclear Waste Management III, G.B. Mellinger, ed., 9, p. 307 (1990).

42. M. Brandys, M. Gong, R.E. Sasson, A. Barkatt and P.B. Macedo, "Analysis of Brine Leachates from MIIT- 2. Leaching of Lithium and Zirconium from Nuclear Waste Glass", Ceramic Transactions, Nuclear Waste Management III, G.B. Mellinger, ed., 9., p. 287 (1990). 